Available online at GSC Online Press Directory

GSC Biological and Pharmaceutical Sciences

e-ISSN: 2581-3250, CODEN (USA): GBPSC2

Journal homepage: https://www.gsconlinepress.com/journals/gscbps

(REVIEW ARTICLE)

\title{
Review on synthetic study of benzotriazole
}

\author{
Avhad Datta *, Asnani Alpana, Mohurle Shrikant, Kumar Pratyush, Bais Abhibnav and Tale Ruchita \\ Department of Pharmaceutical Chemistry, Priyadarshini J. L. College of Pharmacy, Nagpur-440016, (Maharashtra), \\ (India).
}

Publication history: Received on 11 May 2020; revised on 20 May 2020; accepted on 22 May 2020

Article DOI: https://doi.org/10.30574/gscbps.2020.11.2.0137

\begin{abstract}
Benzotriazole is nitrogen containing heterocycle derivative containing three nitrogen atoms at $1 \mathrm{st}, 2 \mathrm{nd}, 3 \mathrm{rd}$ positions. Lone pairs of each nitrogen atom are present in unshared form. The unshared lone pair of electrons enables fivemembered ring to exhibit that can exist in tautomeric forms. Benzotriazole belongs to a fused heterocycles, which has a benzene ring fused with with a traizole ring. Benzotriazole and its derivatives have great significance in medicinal chemistry. The derivatives are used by several chemists for therapeutic conditions. The current paper concise several synthetic methods utilized for synthesizing derivativeswhich acts as antimicrobials, antibacterial, antifungal, antiviral, antitubercular, anticancer, anti-inflammatory, anticonvulsant, analgesic and antioxidant agents. The article will also help the researchers to understand the structure activity relationships and improvise the conceptsin their researches.
\end{abstract}

Keywords: Benzotriazole; Antimicrobial; Anticancer; Antifungal; Fused heterocycles

\section{Introduction}

As the micro-organisms are rapidly undergoing genetic changes and developing resistance against many antibiotics and therapeutic agents for various diseases more quickly than new drugs are being made available so the war against the infectious diseases has become a never ending process. Over the past few decades, there are great interest of triazole class arising due to their wide use in industry and agriculture. Benzotriazole and its derivatives have great significance in medicinal chemistry [1].

The incorporation of the Benzotriazole nuclei is an important synthetic strategy in drug discovery. The high therapeutic properties of the related drugs have encouraged the medicinal chemists to synthesize the large number of novel chemotherapeutic agents [2].

In general, nitrogen and sulfur containing organic compounds and their metal complexes display a wide range of biological activity as antitumor, antibacterial, antifungal and antiviral agents [3]. Benzotriazoles are often used as corrosion inhibitors, radioprotectors, and photo stabilizer in the production of plastic, rubber and chemical fiber 3. Along with these activities, benzotriazole is also important as a precursor in the synthesis of peptides, acid azides, preparation of 3hydroxymethyl-2,3-dihydrobenzofurans and 3-hydroxymethylbenzofurans [4].

$\mathrm{N}$-Substituted benzotriazoles exist as two isomers: $1 \mathrm{H}$ - and $2 \mathrm{H}$-substituted. It is generally agreed that $1 \mathrm{H}$-substituted dominated in solid and solution, whereas the proportion of the $2 \mathrm{H}$-tautomer increased in the gas phase [5]. However, the energy difference between the two isomers is very little [6]. Similarly, benzotriazoles containing Mannich bases have recently been synthesized also by amine exchange reactions, from the $\mathrm{N}, \mathrm{N}$-dimethylaminopropiophenone hydrochlorides and benzotriazole, respectively [7].

\footnotetext{
* Corresponding author: Avhad Datta
} 


\subsection{Structure of Benzotriazole with their properties}<smiles>c1ccc2[nH]nnc2c1</smiles>

$\mathrm{H}$
Molecular Formula: $\quad \mathrm{C}_{6} \mathrm{H}_{5} \mathrm{~N}_{3}$

Formula Weight: $\quad 119.124$

Composition: $\quad \mathrm{C}(60.50 \%) \mathrm{H}(4.23 \%) \mathrm{N}(35.27 \%)$

Molar Refractivity: $\quad 34.71 \pm 0.3 \mathrm{~cm}^{3}$

Molar Volume: $\quad 88.3 \pm 3.0 \mathrm{~cm}^{3}$

Index of Refraction: $\quad 1.715 \pm 0.02$

Surface Tension: $\quad 73.9 \pm 3.0$ dyne $/ \mathrm{cm}$

Density: $\quad 1.348 \pm 0.06 \mathrm{~g} / \mathrm{cm}^{3}$

Dielectric Constant: Not available

Polarizability: $\quad 13.76 \pm 0.510^{-24} \mathrm{~cm}^{3}$

\section{Synthesis}

\subsection{Scheme-I for synthesis of benzotriazole}

Benzotriazoles are synthesized by cyclocondensation of o-phenylenediamines with sodium nitrite in acetic acid. The reaction involved the simple heating the reagents together. Conversion of the diamine into the monodiazonium derivative is followed by spontaneous cyclization [8].

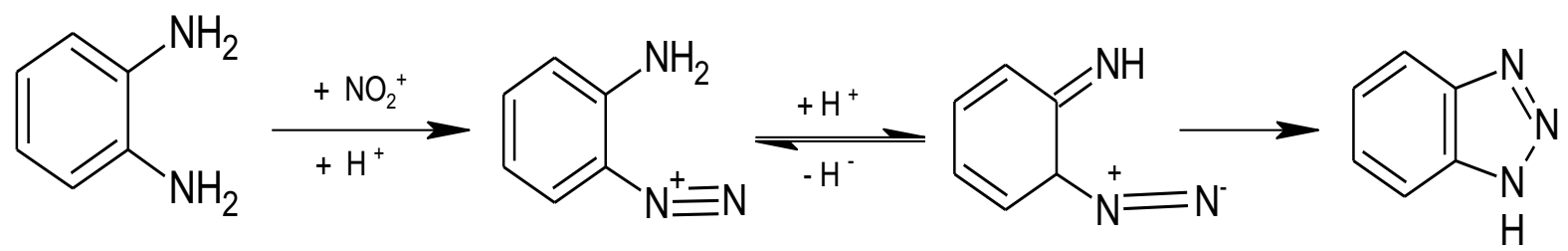

\subsection{Scheme-II}

1,2,3-Benzotriazole has been prepared directly by the action of nitrous acid on $o$-phenylenediamine and by the hydrolysis of an acylated or aroylated benzotriazole which has been previously prepared by the action of nitrous acid on the corresponding mono acylated or aroylated $o$-phenylenediamine. The above procedure is the direct method and gives better over-all yields than the methods involving several intermediate steps [9]<smiles>Nc1ccccc1N</smiles><smiles>[O+][Os]</smiles><smiles>Nc1ccccc1/N=N\O</smiles><smiles>CC(C)O</smiles><smiles>c1ccc2[nH]nnc2c1</smiles>

\subsection{Scheme-III N-Alkylation of Benzotriazole under Solvent-Free Conditions}

N-Alkylation of Benzotriazole under Solvent-Free Conditions: An efficient, simple and solvent-free method for highly regioselective $\mathrm{N}$-alkylation of benzotriazole in the presence of SiO2, $\mathrm{K} 2 \mathrm{CO} 3$ and tetrabutylammonium bromide (TBAB) under thermal and microwave conditions has been described. In this method, 1-alkyl benzotriazoles were obtained regioselectively in moderate to high yields and short reaction times [10]. 


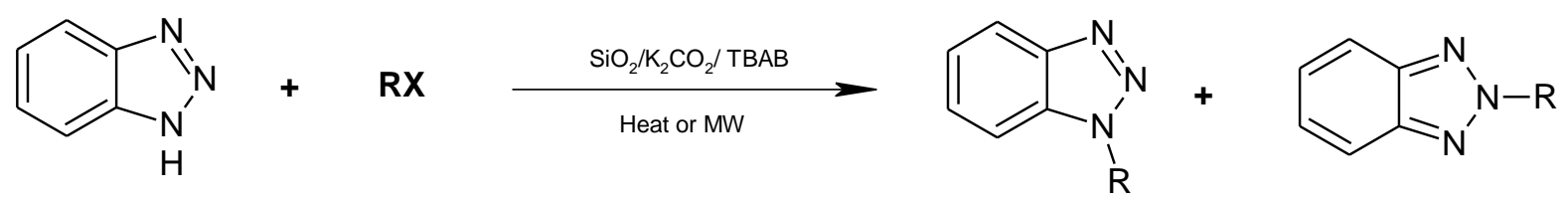

\section{R= Alkyl, Aryl}

Benzotriazoles are formed by cooling and stirring of benzene-1,2-diamine with carboxylic acid. Benzotriazole moiety possessing antifungal activity (Compound $\mathrm{b}$ had good activity) [11].

\section{Pharmacological Study}

\subsection{Antimicrobial activity}

Chloro-, bromo- and methyl- analogues of $1 \mathrm{H}$-benzimidazole and $1 \mathrm{H}$-benzotriazole and their $\mathrm{N}$-alkyl derivatives have been synthesized and tested in vitro against the protozoa Acanthamoeba castellanii. The results indicate that 5,6dimethyl-1Hbenzotriazole and 5,6-dibromo-1H-benzotriazole have higher efficacy than the antiprotozoal agent chlorohexidine.<smiles>CCn1nnc2c(Br)c(Br)c(Br)c(Br)c21</smiles>

Comp.6<smiles>Cn1nnc2c(Br)c(Br)c(Br)c(Br)c21</smiles>

Comp.5<smiles>Cc1cc2nn[nH]c2cc1C</smiles><smiles>C[I-]C</smiles><smiles>[R7]c1c([R7])c([R7])c2c(nnn2[R])c1[R7]</smiles><smiles>[R7]c1c(Cl)c(Cl)cc2[nH]nnc12</smiles>

Comp.3

Figure 1 Derivatives of antimicrobial activity

\subsection{Antiviral activity}

A novel series of dialkylamino side chain derivatives of benzotriazole were synthesized and reported as potential inhibitors of respiratory syncytial virus was found to be most potent in series. 
<smiles>CC(C)CCn1c2ccccc2n[n+]1Cn1nnc2ccccc21</smiles>

Comp.7<smiles>Clc1c(Cl)c(Cl)c2[nH]nnc2c1Cl</smiles>

Comp.8<smiles>Brc1c(Br)c(Br)c2[nH]nnc2c1Br</smiles>

Comp.9

Figure 2 Derivative of antiviral activity

Halogenated benzotriazole nucleosides were synthesized and antiviral activity was tested against hepatitis $\mathrm{C}$ virus and other viral NTPase/helicases was found to be good inhibitor of the West Nile virus enzyme with an RNA substrate (IC50$0.3 \mu \mathrm{m}$ ) also reported selective antiviral activity.

\subsection{Antifungal activity}

1-Carbamoyl-1H-benzotriazole (benzotriazole-1-carboxamide, 2a), an effective carbamoyl chloride substitute, and a range of its analogs can be synthesized in good yields in two very simple steps from 1,2-diaminobenzene. The facile preparation of the intermediate o-aminophenylurea is key to this process. Evaluated antifungal derivatives.<smiles>NC(=O)n1nnc2ccccc21</smiles>

Comp.10<smiles>NC(=S)n1nnc2ccccc21</smiles>

Comp.11

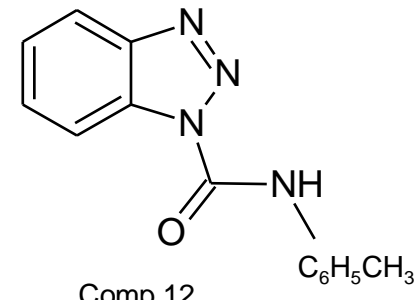

Comp.12

\subsection{Anticancer activity}

4, 5, 6, 7-tetrabromobenzotriazolewas found to be most effective with high selective inhibition against proteinkinase CK2 reported excellent anticancer activity.<smiles>Brc1c(Br)c(Br)c2[nH]nnc2c1Br</smiles>

Comp.13<smiles>Cn1nnc2c(Br)c(Br)c(Br)c(Br)c21</smiles>

Comp.14<smiles>NCn1nnc2c(Br)c(Br)c(Br)c(Br)c21</smiles>

Comp.15

\subsection{Antitubercular Benzotriazole}

Tuberculosis (TB) is a highly infectious disease primarily caused by Mycobacterium tuberculosis. Several types of antitubercular agents such as isoniazide and rifampicin are available for clinic. However, with the frequent occurrence of resistant strains and clinical adverse drug reactions of stomach and gut as well as liver damage, the uses of clinical anti-TB drugs have been limited by the reduced efficacy and inevitable toxic side effects. Therefore, there is necessary to develop new potent anti-tubercular drugs without cross resistance from known antimycobacterial agents. Recently,more and more researches have shown that the nitrogen heterocyclic benzotriazole compounds have considerable potentiality to treat tuberculosis. The substitution of benzotriazole ring by halogen atoms on the benzene ring has been proved to be a useful way to enhance the bioactivity of benzotriazole derivatives. Sydnones have drawn increasing attention in the fields of both heterocyclic chemistry and medicinal chemistry due to their structural features and biological activities. Some amide benzotriazole derivatives synthesized from sydnone fragment were reported to 
display good antitubercular activities. For instance, amino benzotriazole was manifested to be a potent antitubercular agent with better inhibition against $\mathrm{M}$. tuberculosis than standard drugs streptomycin and pyrazinamide.Pyrazole $\mathrm{N}$ aryl derivatives have been deeply investigated in the pharmaceutical field due to their wide range of bioactivities such as anti-hyperglycemic, analgesic, antiinflammatory, antipyretic and antibacterial activities. The introduction of pyrazole ring in molecules could increase the electron density of the system and makes the chromophore more resistant towards enzymatic reduction by radical species [25].

\subsection{Antioxidative Benzotriazoles}

Free radicals, represented by reactive oxygen nitrogen species from human metabolism, could produce harmful substances by a variety of metabolic pathways, then cause healthy problems, such as aging, cancer and many neurodegenerative diseases. Therefore, eliminating the excessive oxidized free radicals, improving the antioxidative activities of the body to resolve the aging-related diseases has been an increasingly important challenge. Antioxidants are reducing agents used to stabilize some free radicals produced by cellular metabolism [26].Benzotriazole compounds have shown remarkable antioxidative activities and large potentiality to be novel antioxidative agents or candidates. Primaquine (PQ) derivatives are wellknown and wide-used antimalarial drugs, meanwhile they are interesting molecules to develop potential antioxidative agents due to their prooxidant effects in blood. Benzotriazole substituted primaquine 58 showed a higher interaction (73.8\%) than the parent compound primaquine (31\%), and it also exhibited a good lipoxygenase inhibitory (LOX) inhibition [27]. In addition, benzotriazole derivative had perfect DPPH interaction value (85\%), which was comparable to that of the reference compound nordihydroguaiaretic acid (91\%) at the same concentration. This compound also displayed a good lipid peroxidation (LP) inhibition of 31\% . These results proved the promising efficiency of the benzotriazole group as a new scaffold inthe rational design of new antioxidant compounds. Ketoprofen (Ket) is a non-steroidal antiinflammatory drug (NSAID) with pronounced analgesic and antipyretic activities. Recently, the structural modification of ketoprofen molecule has afforded a series of derivatives with minimized side-effects, prolonged plasma half life, increased solubility and considerable antioxidative potentiality. For example, ketoprofenbenzotriazole derivative possessed good interaction with 1, 1-dipheny l-2-picrylhydrazyl (DPPH) which was a stable free radical with spared electron delocalization over the whole molecule. The interaction between compound and DPPH indicated its radical scavenging ability in an iron-free system as well as its reducing activity. Moreover, it was proved to be an excellent inhibitor of LP of 98\%, which was significantly higher than that of the standard ketoprofen (69.3\%). This compound also exhibited remarkable soybean LOX activity of 95\% [28]. The replacement of benzotriazole ring by other substituent such as pyrrolyl or piperidyl fragment could obviously reduce the antioxidant activity, which indicated that then presence of benzotriazole was benifical to its antioxidant propriety [28].

Table 1 Various pharmacological activities with their derivatives of Benzotriazole

\begin{tabular}{|c|c|c|c|c|c|}
\hline Sr. No & Authors & Compounds & Derivativ & & Activities \\
\hline 1 & $\begin{array}{l}\text { Farag et al; } \\
1997\end{array}$ & & $\begin{array}{cl} & \mathrm{R} \\
1 & \mathrm{CH}_{3} \\
2 & \mathrm{CH}_{3} \\
3 & \mathrm{CH}_{3} \\
4 & \mathrm{OC}_{2} \mathrm{H} \\
5 & \mathrm{OC}_{2} \mathrm{H} \\
6 & \mathrm{OC}_{2} \mathrm{H}\end{array}$ & $\begin{array}{l}\mathrm{Ar} \\
\mathrm{C}_{6} \mathrm{H}_{5} \\
\mathrm{MeC}_{6} \mathrm{H}_{4} \\
\mathrm{ClC}_{6} \mathrm{H}_{4} \\
\mathrm{C}_{6} \mathrm{H}_{5} \\
\mathrm{MeC}_{6} \mathrm{H}_{4} \\
\mathrm{ClC}_{6} \mathrm{H}_{4}\end{array}$ & $\begin{array}{l}\text { Anticonvulsant } \\
\text { and } \\
\text { Antiinflammato } \\
\text { ry } \\
{[12]}\end{array}$ \\
\hline 2 & $\begin{array}{l}\text { Fatima } \\
\text { Omran Al- } \\
2002\end{array}$ et al; & & 1 & 2 & $\begin{array}{l}\text { Antimirobial } \\
\text { and Antifungal } \\
{[13]}\end{array}$ \\
\hline
\end{tabular}




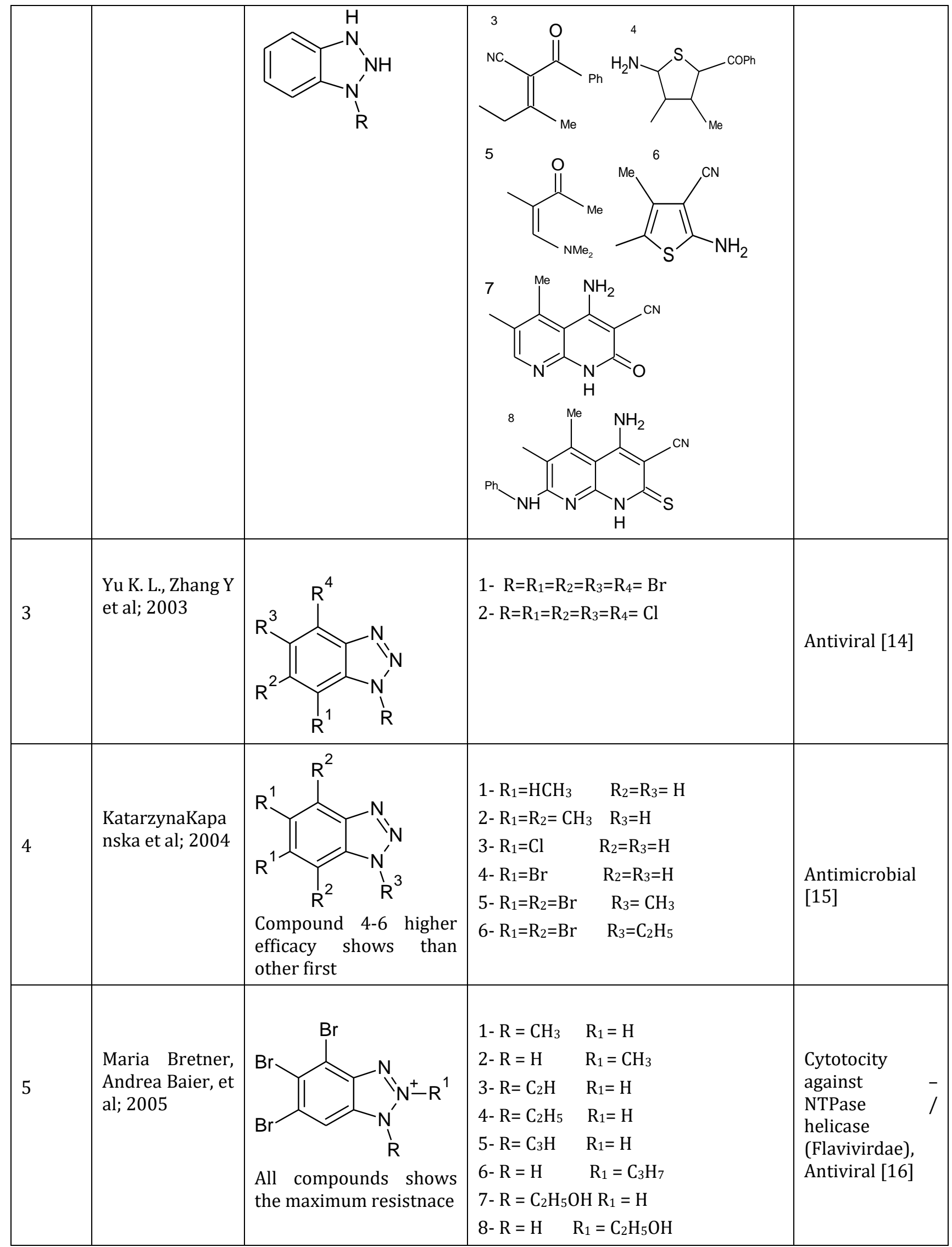




\begin{tabular}{|c|c|c|c|c|}
\hline 6 & $\begin{array}{l}\text { Asati KC et al; } \\
2006\end{array}$ & BTA- Benzotriazole & $\begin{array}{c}\mathrm{Ar}-\mathrm{ClC}_{6} \mathrm{H}_{4} \\
-\mathrm{CH}_{3} \mathrm{C}_{6} \mathrm{H}_{4} \\
-\mathrm{NO}_{2} \mathrm{C}_{6} \mathrm{H}_{2} \\
-\mathrm{Br}_{6} \mathrm{H}_{4}\end{array}$ & $\begin{array}{l}\text { Analgesic and } \\
\text { Antimicrobial } \\
\text { activity [17] }\end{array}$ \\
\hline 7 & $\begin{array}{l}\text { Christopher } \\
\text { John Perry et al; } \\
2008\end{array}$ & & $\begin{array}{ll}A-\mathrm{R}=\mathrm{S} & \mathrm{R}_{1}=\mathrm{C}_{6} \mathrm{H}_{5} \mathrm{CH}_{3} \\
\mathrm{~B}-\mathrm{R}=\mathrm{S} & \mathrm{R}_{1}=\mathrm{C}_{11} \mathrm{H}_{10}\end{array}$ & Antifungal [18] \\
\hline 8 & $\begin{array}{l}\text { JUN WAN et al; } \\
2009\end{array}$ & 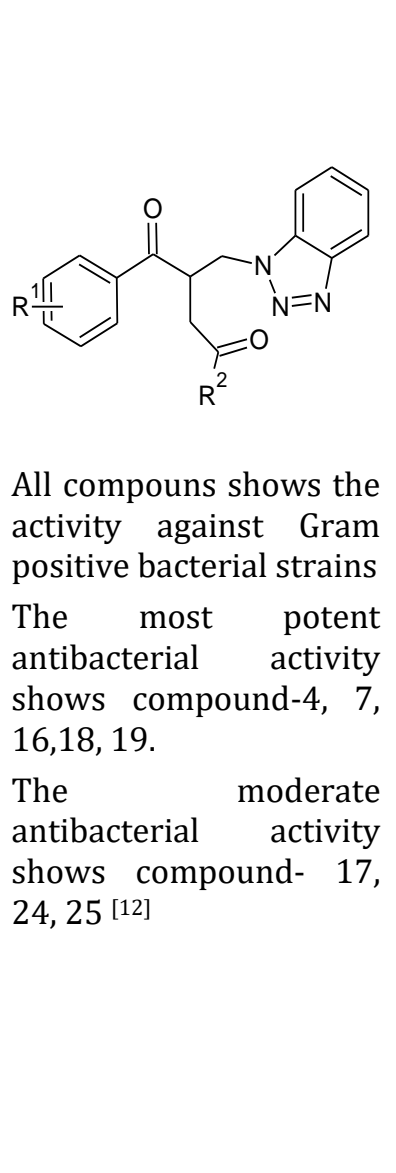 & 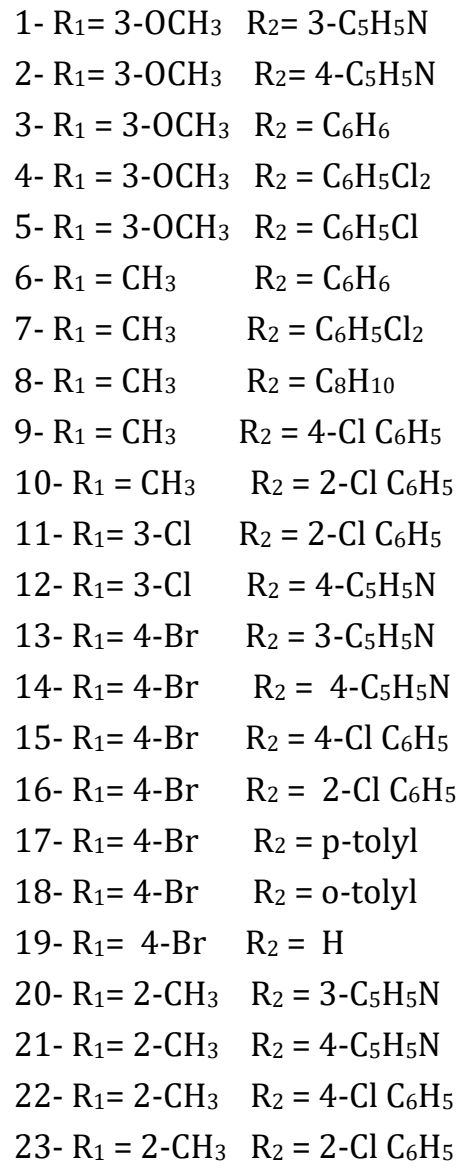 & $\begin{array}{l}\text { Antibacterial } \\
{[19]}\end{array}$ \\
\hline
\end{tabular}




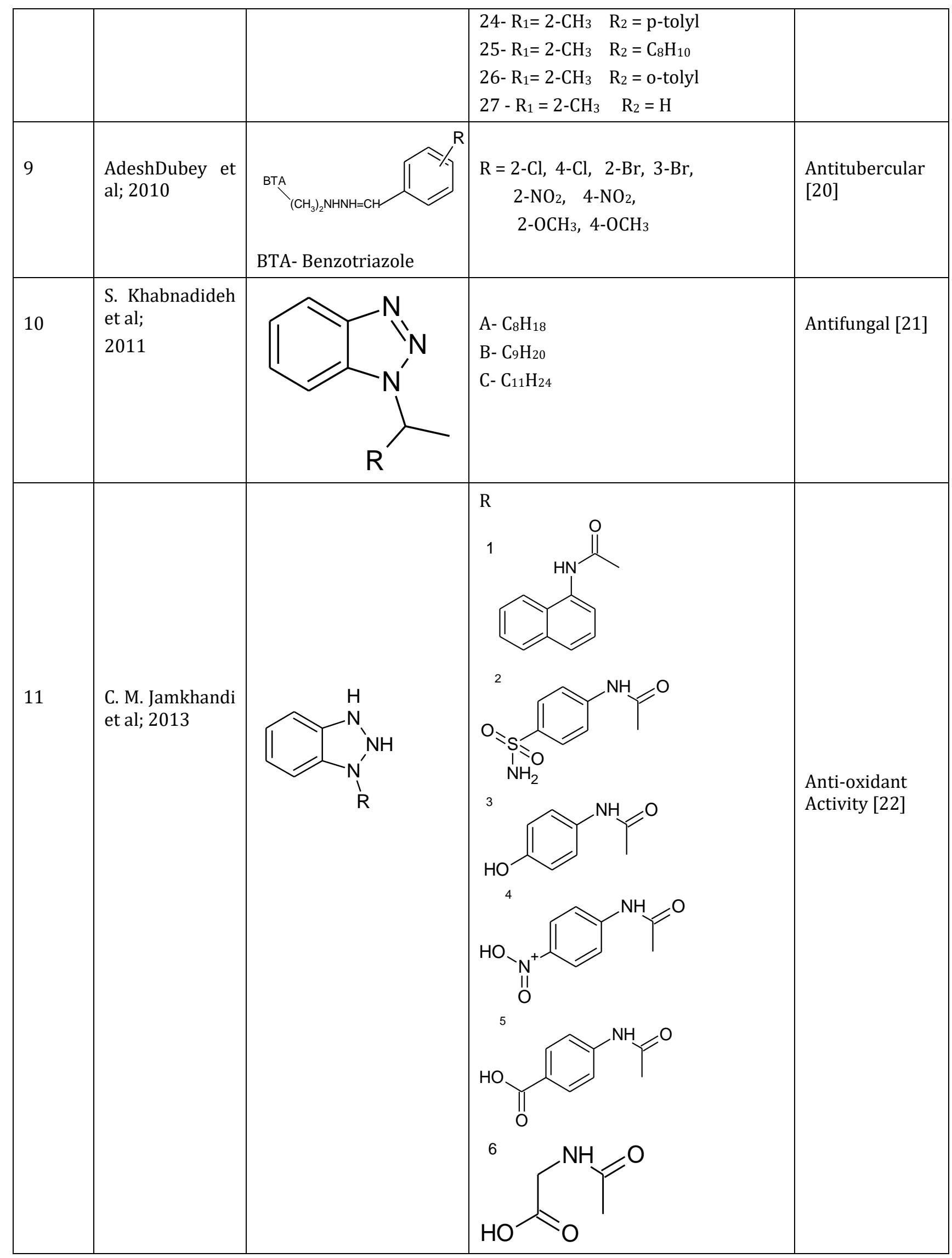




12 (13

\section{Conclusion}

The plethora of research subscribed in this review indicates a wide spectrum of pharmacological activities exhibited by benzotriazole derivatives. The biological profiles of these new generations of benzotriazole would represent a healthy matrix for further development of better medicinal agents.Benzotriazole derivatives is focussed on screening of biological activities such as antibacterial, antifungal, antiviral, antitubercular, anticancer,antimicrobial, antiinflammatory, anticonvulsant, analgesic, antioxidant etc. in which benzotriazole is act as a tagging molecule to deliver other pharmacologically active heterocyclic nuclei. The investigated reports in this review definitely suggests the possibility to develop a lead compound in which benzotriazole is used as a tagging molecule to emerge new chemical entities (NCE's) of benzotriazole having potential pharmacological activity.

On the one hand, an increasing effort is the structural modification by the introduction of benzotriazole ring into available drugs, and focused more on new struactrualbenzotriazolecontaining compounds with novel mechanisms of action. The electron-rich benzotriazole ring with a large conjugated system is an attracting molecular skeleton, which is not only easily modified by various types of functional groups, but also employed to combine with other bioactive fragments to afford more active compounds with remarkable physicochemical properties. 


\section{Compliance with ethical standards}

\section{Acknowledgments}

I thankful to that people, who contributed generously their time to prepare this review paper. We would also like to thank and express our gratitude to HOD and teaching staff of Priyadarshini J L College of Pharmacy, Nagpur.

\section{Disclosure of conflict of interest}

The authors declare that there are no conflicts of interest.

\section{References}

[1] V K Singh, PoonamRishishwar, Peeyush Bhardwaj and ShashiAlok. (2017). Benzotriazole: A Heterocyclic Molecule with Diversified Pharmacological Activities, IJPSR, 8(2), 446-456.

[2] Khalafi-Nezhad A, Soltani Rad MN, Mohabatkar H, Asrari Z and Hemmateenejad B. (2005). Design, synthesis, antibacterial and QSAR studies of benzimidazole and imidazole chloroaryloxyalkyl derivatives. Bioorgan Med Chem, 13, 1931-1938.

[3] Arjmand F, Mohani B and Ahmad S. (2005). Synthesis, antibacterial, antifungal activity and interaction of CTDNA with a new benzimidazole derived Cu (II) complex. Eur J Med Chem, 40, 1103-1110.

[4] Jamkhandi CvM, Disouza J I, Asgekar S D, Sutar TB and Kumbhar PS. (2015). Synthesis, Characterization, in-vitro anti-inflammatory activity and QSAR evaluation of benzotriazolyl-3-\{5-(carboxymethyl) diazenyl\}2hydroxyphenyl prop-2-enoic acid derivatives. European journal of pharmaceutical and medical research, 2 , 302-306.

[5] Tomás F, Catalán J, Pĕrez P and Elguero J. (1994). On the acidity and basicity of azoles: the Taft scheme for electrostatic proximity effects J. Org. Chem. 59, 2799.

[6] Wang H, Burda C, Persy G and Wirz J. (2000). Photochemistry of $1 H$-Benzotriazole in Aqueous Solution: A Photolatent Base J. Am. Chem. Soc. 122, 5849.

[7] Abonia R, Insuastya B, Quirogaa J, Noguerasb M and Meierc H. (2004). Mini-reviews in organic chemistry, 1, 387.

[8] Vogel's Textbook of Practical Organic Chemistry by Brian S. Furniss, Antony J. Hannaford, Peter W. G. Smith \& Austin R. Tatchell, 1163.

[9] Khalafi A, Zare A, Parhami A, Soltani Rad MN and Nejabat GR. (2007). Highly regioselective $N$-alkylation of benzotriazole under solvent-free conditions, J. Iranian Chem. Soc, 4(3),271-278.

[10] Namdeo KP, Singh VK and Prajapati SK. (2009).Synthesis of some 2-(substituted)-5-[(N-benzotriazolomethyl)1,3,4-thiadiazolyl]-4-thiazolidinones for their antifungal activity.Indian J. Pharma. Educ. Res, 43(3), $266-271$.

[11] RE Damschroder and WD Peterson (1955). Organic Syntheses. Coll. Vol. 3, p.106 Vol. 20, p.16 (1940).

[12] Farag, AM, Dawood KM and Kandeel ZE. (1997).Synthesis and reactivity of benzothiazol-2ylcarbonylhydroximoyl chloride, a versatile synthon, Tetrahydron 53, 161.

[13] Fatima Al-Omran, Rafat MMohareb and Adel Abou El-Khair. (2002). "Synthesis and Biological Effects of New Derivatives of Benzotriazole as Antimicrobial and Antifungal Agents" J. Heterocyclic Chem., 39, 877.

[14] Yu KL, Zhang Y, Civiello RL., Kadow KF, Cianci C, Krystal M and Meanwell NA. (2003). Fundamental structureActivity relationships associated with a new structural class of respiratory syncytial virus inhibitor. Bioorganic \& medicinal chemistry letters, 13, 21412144.

[15] KatarzynaKapanska, AndezlikaNajda et al. "Synthesis and activity of 1-H benzotriazole, 1-H benzimidazole as inhibitors of acanthamoebacastellanii; Bioorganic \& Medicinal Chemistry 12 2617-2624

[16] 16] Maria Bretner, Andrea Baier, KatarzynaKopanska, et al.(2004). "Synthesis and biological activity of 1Hbenzotriazole and $1 \mathrm{H}$-benzimidazole analogues - inhibitors of the NTPase/helicase of HCV and of some related Flaviviridae" Antiviral Chemistry \& Chemotherapy, 16, 315-326. 
[17] Asati K C, Srivastava S K and Srivastava S D. (2006). Synthesis of 5-arylidene-2-aryl-3(benzotriazoloacetamidyl)-1, 3-thiazolidin-4-ones as analgesic and antimicrobial agents, Indian J. Chem, 45B, 526-531.

[18] Christopher John Perry, Keith Holding and Elizabeth Tyrrell. (2008). "Simple, Novel Synthesis for 1CarbamoyllH-benzotriazole and Some of Its Analogs" Synthetic Communications: An International Journal for Rapid Communication of Synthetic Organic Chemistry.

[19] Jun Wan, Peng-Cheng Lv et al. (2010). "Facile synthesis of novel benzotriazole derivatives and their antibacterial activities"; J. Chem. Sci, 122(4), 597-606.

[20] Adesh Dubey, SK Srivastava and S D Srivastava. (2011). “Conventional and microwave assisted synthesis of 2oxo-4-substituted aryl-azetidine derivatives of benzotriazole: A new class of biological compounds” Bioorg. Med. Chem. Lett. 21, 569-573.

[21] S Khabnadideh, Z Razaei, K Pakshir et al. (2012). "Synthesis and antifungal activity of benzimidazole, benzotriazole and aminothiazole derivatives"; Res Pharm Sci, 7(2), 65-72.

[22] C M Jamkhandi and John IntruDisouza. (2013). "Evaluation of Antioxidant Activity For Some Benzotriazole Substituted with N-Phenylacetamide and Acetylcarbamic Acid Derivatives" Int J. Pharm PharmSci, 5(2), 249-253.

[23] J J Shah and KrishnapriyaMohanraj. (2014). “Comparison of Conventional and Microwave-assisted Synthesis of Benzotriazole Derivatives" Indian Journal of Pharmaceutical Sciences.

[24] Gitanjali KP, Harshada CP, Indira MP, Prof. SL Borse and Dr. SP Pawar. (2015). "Benzotriazole - The Molecule Of Diverse Biological Activities" WJPPS, 4(5).

[25] Kumar V and Malhotra SV. (2008). Synthesis of nucleoside-based antiviral drugs in ionic liquids. Bioorg Med ChemLett, 18, 5640-5642.

[26] Simunovic M, Perkovic I, Zorc B, Ester K, Kralj M, et al. (2009). Urea and carbamate derivatives of primaquine: synthesis, cytostatic and antioxidant activities. Bioorg Med Chem, 17, 5605-5613.

[27] Perkovic I, Butula I, Kralj M, MartinKleiner I andBalzarini J.(2012). Novel NSAID 1-acyl4cycloalkyl/arylsemicarbazides and 1-acyl-5-benzyloxy/hydroxyl carbamoylcarbazides as potential anticancer agents and antioxidants. Eur J Med Chem, 51, 227-238.

[28] Jain NP, Upasani CD, Kalkotwar RS and Jain UN. (2013). Synthesis and anti-inflammatory activity of N-(alkyl or aryl)-2-(1H-benzotriazol-1-yl) acetamide derivatives. Res J Pharm BiolChemSci, 4, 1470-1480.

\section{How to cite this article}

Avhad D, Asnani A, Mohurle S, Kumar P, Bais A and Tale R. (2020). Review on synthetic study of benzotriazole. GSC Biological and Pharmaceutical Sciences, 11(2), 215-225. 